\title{
Higher Education in Economic Development of Saudi Arabia: A Literature Review
}

\author{
Dr. Zertaj Fatima*, Hayam M Jabali
}

Coordinator Faculty Office Management Department Business Management Department Community College for Girls, Jazan University, Al Maarefah Rd, Jazan Saudi Arabia

DOI: $10.36347 /$ sjebm.2020.v07i01.010

| Received: 05.12.2019 | Accepted: 12.12.2019 | Published: 30.01.2020

*Corresponding author: Dr. Zertaj Fatima

Abstract Review Article

Higher education prepares students for their future roles and responsibilities so that the student becomes a valuable resource for the nation's economy. In this current study the role of higher education in economic development of Saudi Arabia is examined through the viewpoint of female workforce individuals in colleges of Jazan University. How their work prospects increments after gaining higher education. The study is based on primary and secondary data collection method. Primary data is collected using questionnaire method and secondary data is collected through websites. A survey questionnaire strategy is applied to conduct the interviews with female workforce individuals of different colleges in Jazan University in order to gain their knowledge and perception towards professional growth in educational development after they completed their higher education.

Keywords: Economic Development, Higher education, nation's economy.

Copyright @ 2020: This is an open-access article distributed under the terms of the Creative Commons Attribution license which permits unrestricted use, distribution, and reproduction in any medium for non-commercial use (NonCommercial, or CC-BY-NC) provided the original author and source are credited.

\section{INTRODUCTION}

According to [1] the role of higher education in economic development is dependent on investments in education, learning and training, among others. Nowadays universities getting aware of the basic role that higher education plays within the development of knowledge-based economies. The kingdom of Saudi Arabia (KSA) has adopted the drive towards a knowledge-based economy through focusing on the higher education sector. Saudi Universities are playing a pivotal role towards the kingdom's move into a knowledge-based economy and thus achieving economic development and advancement.

\section{RESEARCH LITERATURE}

According to Ozturk, I [2] Education in each sense is one in every of the basic factors of development. It improves the standard of their lives and ends up in broad social edges to people and society. Education raises people's productivity and power and promotes entrepreneurship and technological advances. Additionally, it plays an exceptionally crucial role in securing economic and social progress and rising financial gain distribution.

Saleh, M. A [3] in his research article seeks to trace the event of upper education within the Kingdom of Saudi Arabia from its origins to the current day. The study includes discussion of the historical roots of education as supported Islam, Muslim philosophy of education, the aims and objectives of higher education and fashionable university education. Empirical statistics square measure given to substantiate the Kingdom's fast progress in instruction. Since 1957 once fashionable university education began with one establishment with twenty-one students and workers of 9 it's big till twenty-five years later in 1982 instruction had big to seven establishments with sixty three, 563 students and teaching workers. The study examines these aspects of upper education; Saudi students finding out abroad, foreign students finding out in Asian country, feminine education, the role of the Ministry of upper [4]. In their research expressed the need to stress fastidiously that higher education's purpose isn't reducible to the economic domain. Rather, we tend to request to have interaction with the controversy around one in every of higher education's multiple functions the assembly of practiced graduates for the economy. Significantly, our analysis of the 2 cases stresses the importance of the intersection between the worldwide, national, sectorial and abstraction dimensions once puzzling over the affiliation between education and economic development. It shows however these vary significantly and the way dynamics at multiple scalar 
levels add advanced ways that to form prospects for development.

Hamdan, A [5] in her research presented the historical socioeconomic associate in nursing political conditions of Asian nation area unit an essential facet of understanding a woman's position in Saudi society. In 1980, there were a lot of feminine graduates within the humanities than male. University girls may study most of the constant subjects as their male counterparts except those, which could lead to their inter mixture with men. Her paper explores a number of the restraints and achievements of girls within the field of education in Asian nation these days.

Kashisaz, \& Mobarak [6] in their study indicated the quality of specialities programs offered by personal universities and schools needed within the market within the era of data economy.

According to the research done by [7] the barriers that interchange front of women's education, their pedagogy opportunities have hyperbolic with the development of feminine pedagogy provision however the opportunities are still ineffectual to provide the amount of education required to fulfill the demand of ladies or offer to supply to produce equality of access across the country.

According to [8] Saudi ladies suffer from an occasional level of education and lack of employment opportunities. She emphasizes that bound social and cultural factors move to influence the women's expertise as victims of economic condition.

However, the wave of globalization impacts on women's status; whereby argues there's a world movement of women, that looks to bear in mind of the neoliberal discourse to free itself from the economic and politic determinants.

This improvement within the economic and social status of ladies would balance the economic equation. Saudi ladies don't seem to be far away from this movement, wherever several developments have occurred in their standing up to now.

In the research [9] examined the predominance of views on women's leadership, that systematically emphasize the underrepresentation of girls in just about each sphere of political and economic life in countries round the world,

Little or no is thought regarding women's leadership, particularly in teaching, within the Kingdom of Kingdom of Saudi Arabia (KSA).

This has resulted in a very gap within the literature, since teaching is one space of employment wherever Saudi ladies have created progress, and in spite of complicated social, Religious, cultural and organizational barriers some have broken through the cap into teaching leadership.

One goal of this paper is to spotlight, through a synthesis of existing literature, this state of women's teaching leadership in Kingdom of Saudi Arabia.

Permani, R [10] in research paper investigated the results of upper education curricula on the labour and so on economic process in Taiwan over the 19652000 amount.to look at the potential differential effects of information structure, four educational disciplines in education in Taiwan were chosen. Additionally, outputs were divided into 3 industrial sectors to look at whether or not completely different educational disciplines have differential effects on economic development in every sector.

Dauda, R. O. S [11] current study is an effort to supply empirical proof on the impact of higher education proxies by tertiary faculty registration and graduate turnout on economic process in Nigeria throughout the the information used for the study were obtained from the financial organization of Nigeria and therefore the Nigerian National Bureau of Statistics. This paper employs co-integration and error correction techniques for the information analysis. The study reveals that education will not solely have positive impact on growth of the Nigerian economy however such impact is powerful and statistically important. The empirical results indicate that semi-permanent equilibrium relationship exists between education development and economic process in Nigeria.it absolutely was discovered that labor force and physical capital exert positive and important influence on growth whereas political instability proxies by a dummy variable and rate have negative The policy implication of this study is that government ought to listen to policies that enhance labor productivity and stimulate growth through adequate investment on higher education underneath stable

According to Cortese, A. D [12] Planners should be ready to perceive and articulate the necessity and blessings of higher education establishments being leaders in making a property society to a large variety of stakeholders. These embody internal call makers and different stakeholders (e.g., faculty, operational personnel, students) and external stakeholders (e.g., parents, alumni, native and regional communities, future employers, funders of education.

\section{Objectives and Importance of the research to the community Objectives}

- To investigate the role of higher education in economic development of Saudi Arabia.

- To investigate the female faculty perception and participation of higher education in economic development of Saudi Arabia. 


\section{Importance of the Research to the Community}

The importance of this investigation towards community is to show the role part and prospects of higher education in economic development of Saudi Arabia through the viewpoint and suppositions given by female workforce individuals of Jazan University.

\section{RESEARCH MATERIALS AND METHODS RESEARCH QUESTION}

- What is the role of higher education in economic development of Saudi Arabia?

- What is the perception and participation of female faculty members in economic development of Saudi Arabia?

\section{RESEARCH MATERIALS}

The study is based on primary and secondary data collection method. Primary data is collected using questionnaire method and secondary data is collected through websites.

\section{CONCLUSION}

A survey questionnaire strategy is applied to conduct the interviews with female workforce individuals of different colleges in Jazan University in order to gain their knowledge and perception towards professional growth in educational development after they completed their higher education.

The estimated result shows that with the help of higher educational skills female workforce can increase the productivity value towards developing the nation's economy.

\section{REFERENCES}

1. Salem MI. The role of universities in building a knowledge-based economy in Saudi Arabia. International Business \& Economics Research Journal (IBER). 2014 Aug 23;13(5):1047-56.

2. Ozturk I. The role of education in economic development: a theoretical perspective. Available at SSRN 1137541. 2008.
3. Saleh MA. Development of higher education in Saudi Arabia. Higher Education. 1986 Jan 1;15(12):17-23.

4. Kruss G, McGrath S, Petersen IH, Gastrow M. Higher education and economic development: The importance of building technological capabilities. International Journal of Educational Development. 2015 Jul 1;43:22-31.

5. Hamdan A. Women and education in Saudi Arabia: Challenges and achievements. International Education Journal. 2005 Mar;6(1):42-64.

6. Kashisaz S, Mobarak E. The Effects of Private Education Institutes in Providing Modern Financial Knowledge in Developing Countries. Journal of Humanities Insights. 2018 Dec 1;2(04):172-8.

7. Al Alhareth $\mathrm{Y}, \mathrm{Al}$ Dighrir I, Al Alhareth Y. Review of women's higher education in Saudi Arabia. American Journal of Educational Research. 2015;3(1):10-5.

8. Alyami RH. Saudi Women's Education and Work Opportunities: Equity Matters. Reading: University of Reading. 2016. Available online: http://centaur. reading. ac. uk/59581/3/19000042_\% 20Alyami_s2. pdf (accessed on 1 September 2017).

9. Alsubaie A, Jones K. An overview of the current state of women's leadership in higher education in Saudi Arabia and a proposal for future research directions. Administrative Sciences. 2017 Dec;7(4):36.

10. Permani R. The role of education in economic growth in East Asia: A survey. Asian-Pacific Economic Literature. 2009 May;23(1):1-20.

11. Dauda RO. Higher Education and Economic Growth in Nigeria: An Empirical Investigation. 2011.

12. Cortese $\mathrm{AD}$. The critical role of higher education in creating a sustainable future. Planning for higher education. 2003 Mar 15;31(3):15-22. 